\title{
Gasless laparoscopy versus conventional laparoscopy and laparotomy. A systematic review on the safety and efficiency
}

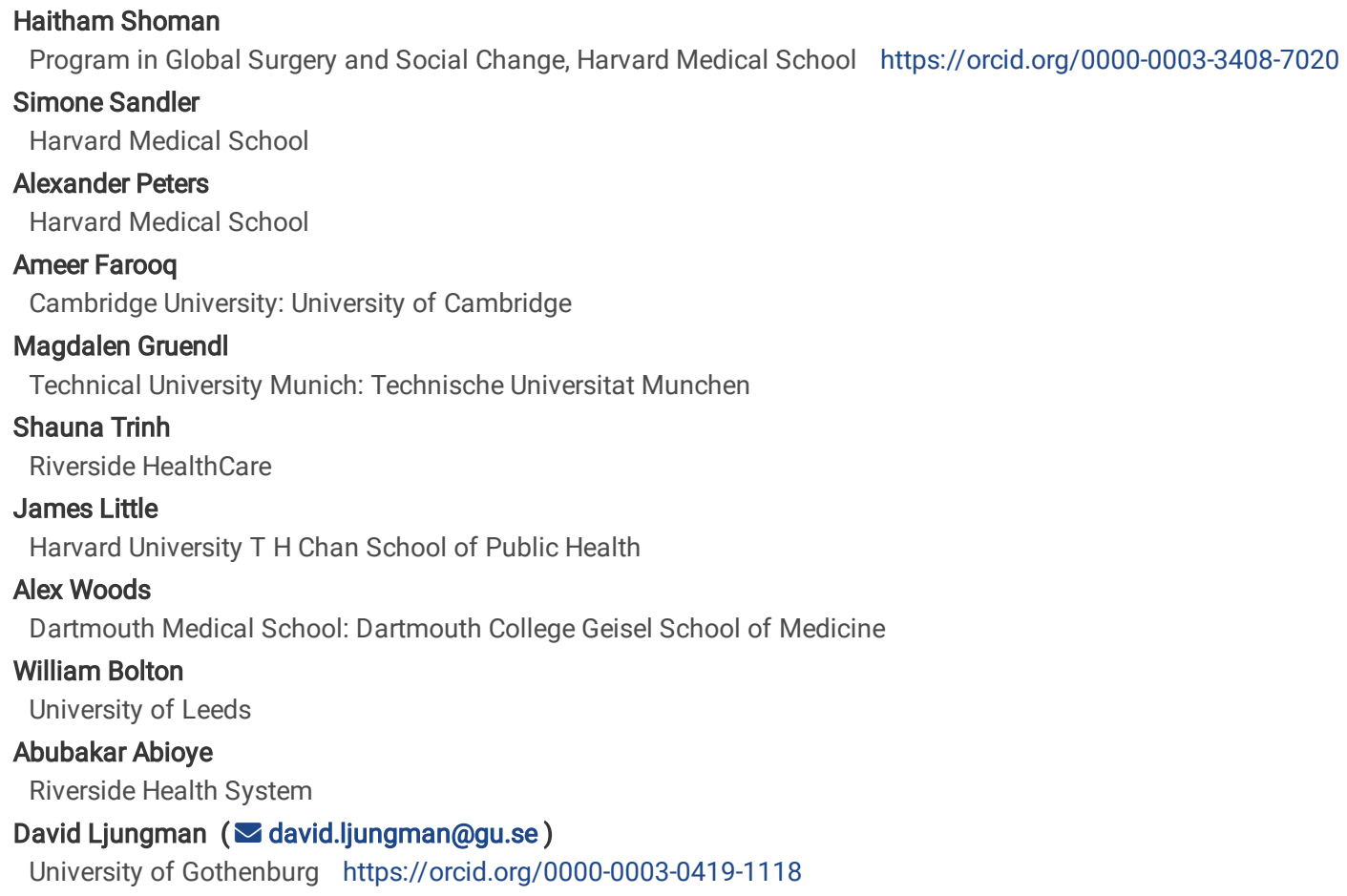




\section{Abstract}

Background Gasless laparoscopy emerged to overcome the clinical and financial challenges of pneumoperitoneum and is often seen as a viable option for use in resource-limited settings as a means of saving costs and resources. This study aims to systematically review the evidence available on the safety and efficiency of gasless laparoscopy compared to conventional laparoscopy and laparotomy.

Methods Following PRISMA guidelines, Medline, Embase, Web of Science and Cochrane were searched. Variables of interest were determined a priori and Covidence software was used to screen studies for inclusion without demographic preference. The quality of studies was assessed using the Cochrane Risk Assessment tool.

Results Of 1080 screened studies a total of 43 studies were included. Laparoscopic cholecystectomy was by far the most studied intervention in randomized studies. In these, the mean set-up time for gasless and conventional laparoscopy was 13.14 (95\% Cl: $-0.16-26.44)$ and 12.8 (95\% Cl: $-10.86-36.47)$ minutes respectively; The mean duration of surgery for gasless and conventional laparoscopy was 89.39 (95\% $\mathrm{Cl}: 77.44-101.34)$ and 72.59 (95\% $\mathrm{Cl}$ : $63.44-81.74)$ minutes respectively and the mean length of stay was 4.25 (95\% Cl: $2.02-6.48)$ and 4.04 (95\% Cl: 1.72-6.36) days respectively. Most reported complications were hemorrhage and infection with no assessable statistical difference.

Conclusions Although gasless laparoscopy seems to be a feasible approach for many general surgery interventions, the observed outcomes based on safety and efficiency don't suffice to recommend gasless laparoscopy as an alternative to conventional laparoscopy or laparotomy. Larger randomized trials with a low risk of bias are warranted.

\section{Introduction}

Around five billion people worldwide lack access to safe, timely and affordable surgical, obstetrics and anesthesia care (1). Due to lack of data, it becomes difficult to estimate the burden of abdominal surgical conditions (2). It is worth noting that a Global Burden of Disease study estimates the global mortality rate due to appendicitis is 0.7 , biliary and liver conditions is 1.6 and intestinal obstruction is 3.9 per 100,000 population (3). A study in India showed that $1.1 \%$ of deaths (0-69 years) are attributed to acute abdominal conditions (72,000 deaths in 2020) (4). In high income settings, these conditions are managed using diagnostic imaging or diagnostic laparoscopy. The increased utilization of laparoscopy over laparotomy stems from several benefits such as reducing pain, reducing wound infection, promoting faster post-operative recovery and return to quality of life (5-9). However, laparoscopic abdominal surgery is resource intensive, requiring expensive surgical equipment, extensive training, general anesthesia and a ventilator to safely manage the abdominal insufflation.

In lower income settings, conventional laparoscopy is often unaffordable due to expensive air-tight trocars, limited availability of carbon dioxide gas and lack of general anesthesiologists needed for patients undergoing pneumoperitoneum and ventilator support (10). Patients may instead undergo laparotomy or go without surgery. Hence, many conditions are untreated, or undiagnosed because of the lack of diagnostic equipment and procedures. This leads to increased morbidity and mortality that could have been avoided by prompt access to resources.

In the early 1990's gasless laparoscopy was introduced in a small scale primarily in resource limited settings, as a means to avoid the financial and clinical challenges associated with pneumoperitoneum and general anesthesia (11). The pneumoperitoneum is avoided by mechanical elevation of the anterior abdominal wall using a planar lifting system, inflatable balloon or other means to allow an overview of the abdominal organs. Several procedures such as gynecological (12-14), upper or lower gastrointestinal (15-20) and exploratory diagnostic procedures (21) have been performed through single or multiple incisions using a gasless technique.

The technique has been described and evaluated in several small studies and safety outcomes such as peri-operative complication rates (22-24) and efficiency outcomes $(19,25)$ have been compared with conventional intervention methods.

Gasless laparoscopy has been proposed to have a variety of potential benefits. One key benefit is the lower cost compared to conventional laparoscopy due to less expensive equipment, maintenance and anesthesia needs (24-26) as it can be used under spinal or local anesthesia $(17,27,28)$. It could thereby act as a diagnostic option in resource-limited settings. Some studies have reported gasless laparoscopy to be associated with shorter duration of hospital stay for inpatients $(26,29)$. Others suggest that gasless laparoscopy decreases the hemodynamic burden due to abdominal insufflation in patients with hemodynamic compromise (e.g., exploratory laparoscopy for abdominal trauma) $(17,27,28)$. Other suggested benefits are improved safety outcomes in pregnancy, reduced post-site metastasis rates and reduced contamination in some procedures (30-32). On the other hand, some authors have reported that gasless laparoscopy may carry a risk of poor visualization during the surgery, but suggest that there is no clinical significant difference in comparison to conventional laparoscopy $(18,31)$.

Since gasless laparoscopy has been developed only in the last two decades, the extent of utilization in resource limited settings is still limited. In addition, there have been several gasless products designed and trialed but it's not yet clear which technique or design is better and in which contexts (12, 17, 33, 34). Also, only a few trials have used strict criteria in patient's eligibility for surgery and presence of comorbidities and randomization when evaluating the technique $(15,26,35)$. Moreover, it is not clear how the introduction of the technique and training for surgeons have been managed before performing the trials to help ensure safety and efficiency of gasless laparoscopy which is crucial when a new technique is being introduced (10).

This systematic review aims to comprehensively examine the available literature on the safety and the efficiency of gasless laparoscopy versus other treatment modalities such as conventional laparoscopy or laparotomy for various procedures across different study designs.

\section{Methods}




\section{Study design}

This systematic review is designed following the Preferred Reporting Items for Systematic Reviews and Meta-analysis Protocol guidelines (PRISMA) statement guidelines (36). The study was registered in the International Prospective Register for Systematic Reviews and Meta-analysis (PROSPERO) with registration number CRD42017078338 and the protocol of the study has been published (10).

\section{Search strategy}

A search across MEDLINE, Embase, Web of Science and Cochrane Central, Global Index Medicus from the World Health Organization (WHO), and the National Institutes of Health clinical trials database using both automated and manual search was used to identify studies and records were combined using the Boolean terms AND/OR. Covidence software (Covidence.org - Melbourne, Australia) was used to pool and manage all studies found. All duplicates were identified by the software and controlled manually. The combination search terms used is shown in table 1 from MEDLINE. Endnote X9 reference manager software was used for citation.

\section{Study selection}

The inclusion criteria for the included studies follows the population, interventions, comparator, outcomes (PICO) tool where the population of interest are adults of 18 years or more without any restriction to race, gender or geography (table 2). Studies included all procedures that were done in a hospital from 1990 and onwards published in English. All excluded studies were tracked to understand how many studies were excluded based on language (table 3). The intervention used in this study is gasless laparoscopy. Gasless procedures were limited to general surgical procedures or conditions, or any trial involving diagnostic laparoscopy performed for general surgical investigation. It includes any variation of gasless technology and device design, any variation of gasless technique and any variation of a gasless training program. The comparison groups were general surgery patients who had conventional laparoscopy, laparotomy or received no interventions. All study designs were included; such as case-control, cohort, and randomized controlled trials (RCTs). The main outcomes this study investigates are the safety and efficiency of gasless laparoscopy.

\section{Data extraction and analysis}

Eight reviewers participated in the overall review process, with two independent reviewers reviewing each article, and a third senior reviewer to discuss discrepancies. Studies were initially screened based on titles and abstracts followed by full-text screening against the inclusion criteria. Data was extracted into Microsoft Excel and specific variables were identified to for data analysis. The Cochrane risk of bias assessment tool was used to assess the risk of bias across studies. RoB II was used for randomized control trials (RCTs) (37) and the (ROBINS-I) tool was used for bias risk assessment in non-randomized studies (38). Necessary tables and figures were developed based on descriptive statistics using Microsoft Excel and STATA Statistical Software Package.

\section{Data synthesis}

A mixed quantitative and qualitative synthesis was provided based on the strength of evidence for the outcomes of interest with specific focus on the varieties of outcomes between both the control and intervention groups. The data synthesis will include the strengths and limitations of the included studies, heterogeneity of the studies, generalizability of the results to other populations and the variety of settings and different patient outcomes. Furthermore, any alternate explanations from current literature and potential future developments were investigated and discussed.

\section{Results}

The search yielded 1080 studies from all the database searches. As shown in figure 1, 43 studies were selected for full data extraction and analysis. The variation of studies by study design, intervention used and procedures were as follows: gasless laparoscopy (GL) was most extensively studied in patients undergoing cholecystectomies where there were 24 RCTs and 5 cohort studies. The comparator was conventional laparoscopy (CL) in 24 of the RCTs and 4 cohort studies while open laparotomy (OL) was the comparator in 2 cohort gastrectomy procedures as shown in figure 2 . Cholecystectomy was the procedure that was mostly reported as an indication for either $\mathrm{GL}, \mathrm{CL}$ or $\mathrm{OL}$ or both (CL, OL). Due to the heterogeneity of the data, a meta-analysis was deemed nonfeasible in this systematic review, however descriptive statistics were used to pool data for cholecystectomies due to relative homogeneity. For all other procedures a qualitative analysis only was made. Extracted data from all 43 included articles are shown in table 4 $(15,16,19,28,29,33,39-74)$.

The main outcomes of the study examined both the efficiency and safety of GL in comparison to other interventions. Efficiency is reported as the mean set-up time (minutes) of the patient for the operation, mean duration of operation (minutes) and the total length of stay in the hospital (days) for those undergoing cholecystectomies across the 24 RCTs.

\section{Efficiency}

In patients undergoing cholecystectomies, the mean set-up time was 13.14 minutes ( $95 \% \mathrm{Cl}:-0.16-26.44$ ) for GL from RCT studies reporting a total of 123 patients and it was 12.8 minutes ( $95 \% \mathrm{Cl}$ - -10.86 - 36.47 minutes) for $\mathrm{CL}$ from RCT studies reporting a total of 125 patients. The mean duration of operation for GL was 89.39 minutes (95\% Cl: 77.44 - 101.34) from RCT studies reporting a total 614 patients while it was 72.59 minutes (95\% Cl: 63.44 - 81.74$)$ for $\mathrm{CL}$ from RCT studies reporting a total of 633 patients (figure $3 a$ ).

In patients undergoing GL, the mean length of stay in hospitals was 4.25 days ( $95 \% \mathrm{Cl}: 2.02-6.48$ ) from RCT studies reporting a total of 423 patients while it was 4.04 days ( $95 \% \mathrm{Cl}: 1.72-6.36)$ from RCT studies reporting a total of 440 patients (figure $3 b$ ). 
From non-RCT studies such as case-controls and cohorts (10 studies), there were several non-cholecystectomies (e.g.: abdominal trauma, intestinal neoplasm - wedge resection, subtotal gastrectomy, GIST removal, upper GIT stromal cancer, liver cystectomy, gastrectomy, colorectal lesions removal, inguinal hernia herniorrhaphy) that had a variety of duration of operation time. For example, colorectal lesions had the highest duration of operation for studies reporting GL and both (CL and OL) 220 minutes and 256.9 minutes respectively. This was followed by gastrectomy where studies reported a duration of operation for GL and both (CL and $\mathrm{OL}$ ) to be 220.6 minutes and 245.8 minutes respectively. In contrast, liver cystectomies had the lowest duration of operation for GL and studies reporting both (GL and OL) 50.49 minutes and 70.8 minutes respectively. The remaining procedures' duration of operation ranged between 90.8 minutes and 143.8 minutes. Overall, GL had less duration of operation compared to both (CL and OL) except in inguinal hernia herniorrhaphy and upper GIT stromal cancer removal. The overall mean duration of operation was 152.66 minutes ( $95 \% \mathrm{Cl}$ : $101.01-204.3)$ for non-RCT studies reporting a total of 217 patients undergoing both $\mathrm{OL}$ and $\mathrm{CL}$ techniques. While, for $\mathrm{GL}$ the mean duration of operation was 135.8 minutes (95\% Cl: 93.37 - 178.23) for non-RCT studies reporting a total of 235 patients (figure $4 a$ ).

From non-RCT studies such as case controls and cohorts (10 studies), there were several non-cholecystectomies (e.g.: abdominal trauma, intestinal neoplasm - wedge resection, GIST removal, upper GIT stromal removal, liver cystectomy, gastrectomy, colorectal lesions removal) that had a variety of length of stay in hospitals as inpatients. Those who had a gastrectomy had the overall highest length of hospital stay for those who underwent $\mathrm{GL}$ and both $\mathrm{OL}$ and $\mathrm{CL}$ at 18.7 and 20.9 days respectively. In contrast, those who were admitted for liver cystectomy undergoing GL and both (OL and/or CL) had the lowest length of hospital stay at 3 days for each technique. The rest of the range of lengths of hospital stay across all admissions for all techniques was between 4.5 and 10 days. GL consistently had lower length of hospital stays across all admissions. The overall mean length of hospital stay was 7.54 days (95\% $\mathrm{Cl}$ : $2.78-12.31$ ) for those who had GL (across 167 patients from the non-RCT studies) and for those who had both (CL and/or OL) it was 9.01 days (95\% Cl: 3.72 - 14.31) (across 155 patients from non-RCT studies) (figure 4b).

\section{Safety}

The safety of the surgical techniques has been structured into three main categories: surgical complications, readmissions to hospitals and all-cause mortality. There were five main complications identified as resulting from undergoing gasless laparoscopy, conventional laparoscopy, laparotomy or both including: wound infection, deep tissue infection, hemorrhage, hemodynamic instability and visceral injury.

Hemorrhage was the mostly reported complication in eight studies for patients undergoing $\mathrm{GL}$, eight studies for patients undergoing $\mathrm{CL}$, one study in $\mathrm{OL}$ and one study in those who had both (CL and/or OL). This was followed by visceral injuries where GL contributed to visceral injury in seven studies, $\mathrm{CL}$ in six studies and both (CL and/or OL) in two studies. Next was hemodynamic instability reported in six GL studies, six CL studies, one study in OL and one study in both (CL and/or OL). Deep tissue infection was then reported in seven GL studies, four CL studies and one both (CL and/or OL) study. Finally, wound infection was reported in seven $\mathrm{GL}$ studies, three $\mathrm{CL}$ studies and two both (CL and/or OL) studies.

Readmissions was reported equally in five studies for those who underwent GL and five studies for those who underwent CL. Only one study reported all-cause mortality in GL (figure 5).

\section{Risk of bias assessment}

More than $50 \%$ of the randomized control trial studies reported low risk of bias as shown in figure $6 a$, except in allocation concealment showing around $35 \%$ of studies had a low risk of bias, and per study risk of bias analysis is shown in figure $6 \mathrm{~b}$. Around $75 \%$ of non-randomized studies had low risk of bias except around $35 \%$ of studies showed low risk of confounding and selection bias shown in figure $7 a$, and the per study risk of bias analysis is shown in figure $7 b$.

\section{Discussion}

This systematic review identified 43 studies that were eligible for inclusion to look at the safety and efficiency of gasless laparoscopy in comparison to conventional laparoscopy or laparotomy or both. There was a total of 25 RCTs and 17 non-RCT studies.

Safety was assessed based on post-operative complications, readmissions and all-cause mortality. Overall post-operative complications and readmissions were reported very similar for GL, CL and OL across all study designs and procedures. The complications found were wound and deep tissue infections, hemorrhage, hemodynamic instability and visceral injury. However, in GL, there were three additional studies that reported wound and deep tissue infections compared to other interventions. There might not be a significant difference to warrant a reason of why there are more infections post $\mathrm{GL}$ compared to $\mathrm{CL}$ or $\mathrm{OL}$, however, there might be a slightly increased risk during the use of the retractor, Laparo-lift or the Laparo-tensor that is introduced through the abdominal wall during the abdominal wall lifting in GL (75). Gurusamy et al (75) looked at GL only in cholecystectomy in a review study until 2011 while our study includes a wider span of conditions and compares $\mathrm{GL}$ to $\mathrm{CL}$ and $\mathrm{OL}$ including studies published over the last decade, hence suggesting this increased risk. Efficiency was assessed based on the set-up time, duration of operation in minutes and length of hospital stay in days. In those undergoing cholecystectomies, the set-up time of operation for $\mathrm{GL}$ and $\mathrm{CL}$ were almost the same. This shows that there is no much difference in setting up the patient for the procedure regardless of the type of laparoscopy.

RCT studies showed that in cholecystectomies only, the average duration of operation for GL was 89 minutes compared to 73 minutes for CL. GL for cholecystectomies might have taken a longer duration of operation due to the low surgical site exposure available for surgeons to navigate the blades during the procedure as also reported in a study by Vezakis et al who showed that intra-operative cholangiography was more successful in $\mathrm{CL}$ compared to $\mathrm{GL}$ (76). The inadequate exposure could be explained by the flat-topped pyramid space limited to the specific abdominal quadrant, particularly in obese and muscular patients and those with adhesions (76). 
In non-RCT studies, the duration of operation in minutes was higher for those undergoing CL or OL or both for all other diseases (such as abdominal trauma, gastrectomy, tumor removal, hernia and colorectal lesions). On average the mean length of hospital stay in days was higher for those undergoing $\mathrm{CL}$ or $\mathrm{OL}$ or both compared to GL across most of the diseases. This could be explained by some of the adverse effects of pneumoperitoneum used such as increased intraabdominal pressure and absorption of carbon dioxide from the peritoneal cavity or adverse effects of open surgery. Increased intra-abdominal pressure causes cardiopulmonary effects including a push of the diaphragm upwards and hence reducing the pulmonary function (77, 78 ). In addition, it reduces the venous return and stroke volume through splanchnic vasoconstriction, reduction in inferior vena cava, renal and portal venous flow $(79,80)$.

The analysis was done comprehensively using several authors and explored the safety and efficiency of GL, CL and OL which was not embarked on before. In addition, the quality of all papers was assessed for bias and based on our analysis, the overall quality of the included studies was good based on the risk of bias assessment. However, this study still posits some limitations. A meta-analysis was deemed inappropriate due to the lack of quantitative metrics and homogeneity of data. Safety of such interventions could also reflect on the quality of life of the patient which was not explored in any of the studies reflecting a weakness in the studies themselves that were included. Since the risk of bias was relatively high in most RCTs,

\section{Conclusion}

In conclusion, GL seems to be a promising alternative to $\mathrm{CL}$ or $\mathrm{OL}$ in a variety of procedures. However, the lack of homogeneity of data precludes a comprehensive meta-analysis. Hence, the observed outcomes based on safety and efficiency do not suffice to recommend GL as a better alternative to CL for the admitted conditions. Data for cholecystectomies does seem to show non-inferiority and as the cost of GL is considerably lower, this technology should be further investigated. Larger randomized studies in homogenous patient populations with uncomplicated abdominal conditions, where detailed perioperative follow up and data on quality of life and cost is collected, are needed to address this.

\section{List Of Abbreviations}

CL: Conventional Laparoscopy

GL: Gasless Laparoscopy

OL: Open Laparotomy

PICO: Population, Intervention, Comparator, Outcomes

PRISMA: Preferred Reporting Items of Systematic Reviews and Meta-analysis

PROSPERO: International Prospective Register of Systematic Reviews

RCT: Randomized Control Trials

RoB II: Risk of Bias

ROBINS-I: Risk of Bias in Non-randomized Studies

WHO: World Health Organization

\section{Declarations}

Ethical approval and consent to participate: Not applicable

Consent for publication: Not applicable

Competing interests: The authors declare that they have no competing interests

Availability of data and materials: Not applicable

\section{Funding or grant support:}

Open access funding provided through the University of Gothenburg

Author's contributions: The design of the project and review was done by HS, SS, AP, and DL. The drafting of the protocol was done by HS, SS, and AP. All authors have contributed to the protocol editing and approval and DL has been guiding the project direction and choice of journal.

Acknowledgements: We would like to thank Dr. Jesudian Gnanaraj and Dr. Anurag Mishra for their support and direction on topic choice and advice on its significance to the global surgery community. We would also like to thank Professor John Meara for providing infrastructure at the Program in Global Surgery and Social Change, Harvard Medical School.

\section{References}


1. Meara JG, Leather AJ, Hagander L, Alkire BC, Alonso N, Ameh EA, et al. Global Surgery 2030: evidence and solutions for achieving health, welfare, and economic development. The Lancet. 2015;386(9993):569-624.

2. Debas HT, Donkor P, Gawande A, Jamison D, Kruk M, Mock C. Essential Surgery: Key Messages of This Volume--Essential Surgery: Disease Control Priorities, (Volume 1). 2015.

3. Naghavi M, Abajobir AA, Abbafati C, Abbas KM, Abd-Allah F, Abera SF, et al. Global, regional, and national age-sex specific mortality for 264 causes of death, 1980-2016: a systematic analysis for the Global Burden of Disease Study 2016. The Lancet. 2017;390(10100):1151-210.

4. Dare AJ, Ng-Kamstra JS, Patra J, Fu SH, Rodriguez PS, Hsiao M, et al. Deaths from acute abdominal conditions and geographical access to surgical care in India: a nationally representative spatial analysis. The Lancet Global Health. 2015;3(10):e646-e53.

5. Gadacz TR. Update on laparoscopic cholecystectomy, including a clinical pathway. Surgical Clinics of North America. 2000;80(4):1127-50.

6. Shaikh AR, Sangrasi AK, Shaikh GA. Clinical outcomes of laparoscopic versus open appendectomy. JSLS: Journal of the Society of Laparoendoscopic Surgeons. 2009;13(4):574.

7. Suh YJ, Jeong S-Y, Park KJ, Park J-G, Kang S-B, Kim D-W, et al. Comparison of surgical-site infection between open and laparoscopic appendectomy. Journal of the Korean Surgical Society. 2012;82(1):35-9.

8. Velanovich V. Laparoscopic vs open surgery. Surgical endoscopy. 2000;14(1):16-21.

9. Warren O, Kinross J, Paraskeva P, Darzi A. Emergency laparoscopy-current best practice. World Journal of Emergency Surgery. 2006;1(1):24.

10. Shoman H, Sandler S, Peters A, Farooq A, Gruendl M, Trinh S, et al. Safety and efficiency of gasless laparoscopy: a systematic review protocol. Systematic Reviews. 2020;9:1-6.

11. Wang Y, Cui H, Zhao Y, Wang Z-q. Gasless laparoscopy for benign gynecological diseases using an abdominal wall-lifting system. Journal of Zhejiang University SCIENCE B. 2009;10(11):805.

12. Davila GW, Stanford E, Korn A. Prospective trial of gasless laparoscopic Burch colposuspension using conventional surgical instruments. The Journal of the American Association of Gynecologic Laparoscopists. 2004;11(2):197-203.

13. Goldberg JM, Maurer WG. A randomized comparison of gasless laparoscopy and CO2 pneumoperitoneum. Obstetrics \& Gynecology. 1997;90(3):41620.

14. Tintara H, Choobun T, Geater A. Gasless laparoscopic hysterectomy: A comparative study with total abdominal hysterectomy. Journal of obstetrics and gynaecology research. 2003;29(1):38-44.

15. Ge B, Zhao H, Chen Q, Jin W, Liu L, Huang Q. A randomized comparison of gasless laparoscopic appendectomy and conventional laparoscopic appendectomy. World Journal of Emergency Surgery. 2014;9(1):3.

16. Huang C-C, Yang C-Y, Wu M-H, Wang M-Y, Yeh C-C, Lai I-R, et al. Gasless laparoscopy-assisted versus open resection of small bowel lesions. Journal of Laparoendoscopic \& Advanced Surgical Techniques. 2010;20(8):699-703.

17. Jiang J-K, Chen W-S, Yang S-H, Lin T-C, Lin J-K. Gasless laparoscopy-assisted colorectal surgery. Surgical endoscopy. 2001;15(10):1093-7.

18. Nakamura H, Kobori Y, Goseki N, Inoue H, Takeshita K, Endo M, et al. Fishing-rod-type abdominal wall lifter for gasless laparoscopic surgery. Surgical endoscopy. 1996;10(9):944-6.

19. Wu J-M, Yang C-Y, Wang M-Y, Wu M-H, Lin M-T. Gasless laparoscopy-assisted versus open resection for gastrointestinal stromal tumors of the upper stomach: preliminary results. Journal of Laparoendoscopic \& Advanced Surgical Techniques. 2010;20(9):725-9.

20. Zhang G, Liu S, Yu W, Wang L, Liu N, Li F, et al. Gasless laparoendoscopic single-site surgery with abdominal wall lift in general surgery: initial experience. Surgical endoscopy. 2011;25(1):298-304.

21. Hill DJ, Maher PJ, Wood EC. Gasless laparoscopy-Useless or useful? The Journal of the American Association of Gynecologic Laparoscopists. 1994;1(3):265-8.

22. Bossotti M, Bona A, Borroni R, Mattio R, Coda A, Ferri F, et al. Gasless laparoscopic-assisted ileostomy or colostomy closure using an abdominal walllifting device. Surgical endoscopy. 2001;15(6):597-9.

23. Ishida H, Hashimoto D, Inokuma S, Nakada H, Ohsawa T, Hoshino T. Gasless laparoscopic surgery for ulcerative colitis and familial adenomatous polyposis. Surgical Endoscopy And Other Interventional Techniques. 2003;17(6):899-902.

24. Kawamura YJ, Sawada T, Sunami E, Saito Y, Watanabe T, Masaki T, et al. Gasless laparoscopically assisted colonic surgery. The American journal of surgery. 1999;177(6):515-7. 
25. Kruschinski D, Homburg S, Langde S, Kapur A. Dermoid tumors of the ovary: evaluation of the gasless lift-laparoscopic approach. Surgical technology international. 2008;17:203-7.

26. Munakata K, Uemura M, Shimizu J, Miyake M, Hata T, Ikeda K, et al. Gasless transumbilical laparoscopic-assisted appendectomy as a safe and costeffective alternative surgical procedure for mild acute appendicitis. Surgery today. 2016;46(3):319-25.

27. Galizia G, Prizio G, Lieto E, Castellano P, Pelosio L, Imperatore V, et al. Hemodynamic and pulmonary changes during open, carbon dioxide pneumoperitoneum, and abdominal wall-lifting cholecystectomy. Surgical Endoscopy. 2001;15(5):477-83.

28. Larsen J, Svendsen F, Pedersen V. Randomized clinical trial of the effect of pneumoperitoneum on cardiac function and haemodynamics during laparoscopic cholecystectomy. British journal of surgery. 2004;91(7):848-54.

29. Liao C-H, Kuo I-M, Fu C-Y, Chen C-C, Yang S-J, Ouyang C-H, et al. Gasless laparoscopic assisted surgery for abdominal trauma. Injury. 2014;45(5):850-

4.

30. Bouvy ND, Marquet RL, Jeekel H, Bonjer HJ. Impact of gas (less) laparoscopy and laparotomy on peritoneal tumor growth and abdominal wall metastases. Annals of surgery. 1996;224(6):694.

31. Lee SC, Kim KY, Yoon SN, Kim BC, Kim JW. Feasibility of gasless laparoscopy-assisted transumbilical appendectomy: early experience. Journal of Laparoendoscopic \& Advanced Surgical Techniques. 2014;24(8):538-42.

32. Tanaka H, Futamura N, Takubo S, Toyoda N. Gasless laparoscopy under epidural anesthesia for adnexal cysts during pregnancy. The Journal of reproductive medicine. 1999;44(11):929.

33. Hyodo M, Sata N, Koizumi M, Sakuma Y, Kurihara K, Lefor A, et al. Laparoscopic splenectomy using pneumoperitoneum or gasless abdominal wall lifting: A 15-year single institution experience. Asian journal of endoscopic surgery. 2012;5(2):63-8.

34. Maas S, Hage J, Cuesta M. Less traumatic abdominal wall retraction for gasless laparoscopic surgery. Surgical endoscopy. 2000;14(8):769.

35. Guido RS, Brooks K, McKenzie R, Gruss J, Krohn MA. A randomized, prospective comparison of pain after gasless laparoscopy and traditional laparoscopy. The Journal of the American Association of Gynecologic Laparoscopists. 1998;5(2):149-53.

36. Moher D, Liberati A, Tetzlaff J, Altman DG, Group P. Preferred reporting items for systematic reviews and meta-analyses: the PRISMA statement. PLoS med. 2009;6(7):e1000097.

37. Higgins JP, Altman DG, Gøtzsche PC, Jüni P, Moher D, Oxman AD, et al. The Cochrane Collaboration's tool for assessing risk of bias in randomised trials. Bmj. 2011;343:d5928.

38. Sterne JA, Hernán MA, Reeves BC, Savović J, Berkman ND, Viswanathan M, et al. ROBINS-l: a tool for assessing risk of bias in non-randomised studies of interventions. bmj. 2016;355.

39. Alijani A, Hanna GB, Cuschieri A. Abdominal wall lift versus positive-pressure capnoperitoneum for laparoscopic cholecystectomy: randomized controlled trial. Annals of surgery. 2004;239(3):388.

40. Andersson L, Lindberg G, Bringman S, Ramel S, Anderberg B, Odeberg-Wernerman S. Pneumoperitoneum versus abdominal wall lift: effects on central haemodynamics and intrathoracic pressure during laparoscopic cholecystectomy. Acta anaesthesiologica scandinavica. 2003;47(7):838-46.

41. Berberoğlu M, Taner Ş, Dilek O, Demir A, Sarı S. Gasless vs gaseous laparoscopy in the treatment of hepatic hydatid disease. Surgical endoscopy. 1999;13(12):1195-8.

42. Chang SKY, Tay CW, Bicol RA, Lee YY, Madhavan K. A case-control study of single-incision versus standard laparoscopic cholecystectomy. World journal of surgery. 2011;35(2):289-93.

43. Chou T-H, Wu M-H, Wang M-Y, Yang C-Y, Lai P-S, Lin M-T, et al. Gasless laparoscopy-assisted subtotal gastrectomy for early gastric cancer: a novel minimally invasive surgery. Journal of Gastrointestinal Surgery. 2008;12(4):695-700.

44. Egawa H, Morita M, Yamaguchi S, Nagao M, Iwasaki T, Hamaguchi S, et al. Comparison between intraperitoneal CO2 insufflation and abdominal wall lift on QT dispersion and rate-corrected QT dispersion during laparoscopic cholecystectomy. Surgical Laparoscopy Endoscopy \& Percutaneous Techniques. 2006;16(2):78-81.

45. Giraudo G, Contul RB, Caccetta M, Morino M. Gasless laparoscopy could avoid alterations in hepatic function. Surgical endoscopy. 2001;15(7):741-6.

46. Ishikawa M, Nakagawa T, Nishioka M, Ogata S, Miyauchi T, Kashiwagi Y, et al. Costs and benefits of laparoscopic cholecystectomy: abdominal wall lifting vs. pneumoperitoneum procedure. Hepato-gastroenterology. 2006;53(70):497-500.

47. Kim WW, Jeon HM, Park SC, Lee SK, Chun SW, Kim EK. Comparison of immune preservation between CO2 pneumoperitoneum and gasless abdominal lift laparoscopy. JSLS: Journal of the Society of Laparoendoscopic Surgeons. 2002;6(1):11. 
48. Koivusalo A-M, Kellokumpu I, Lindgren L. Gasless laparoscopic cholecystectomy: comparison of postoperative recovery with conventional technique. British journal of anaesthesia. 1996;77(5):576-80.

49. Koivusalo A-M, Kellokumpu I, Ristkari S, Lindgren L. Splanchnic and renal deterioration during and after laparoscopic cholecystectomy: a comparison of the carbon dioxide pneumoperitoneum and the abdominal wall lift method. Anesthesia \& Analgesia. 1997;85(4):886-91.

50. Koivusalo A-M, Pere P, Valjus M, Scheinin T. Laparoscopic cholecystectomy with carbon dioxide pneumoperitoneum is safe even for high-risk patients. Surgical endoscopy. 2008;22(1):61-7.

51. Koivusalo AM, Scheinin M, Tikkanen I, Yli-Suomu T, Ristkari S, Laakso J, et al. Effects of esmolol on haemodynamic response to CO2 pneumoperitoneum for laparoscopic surgery. Acta anaesthesiologica scandinavica. 1998;42(5):510-7.

52. Korkmaz A, Alkış M, Hamamcı O, Besim H, Erverdi N. Hemodynamic changes during gaseous and gasless laparoscopic cholecystectomy. Surgery today. 2002;32(8):685-9.

53. Larsen J, Ejstrud P, Svendsen F, Redke F, Pedersen V, Rahr H. Randomized study of coagulation and fibrinolysis during and after gasless and conventional laparoscopic cholecystectomy. British journal of surgery. 2001;88(7):1001-5.

54. Larsen JF, Ejstrud P, Kristensen JU, Svendsen F, Redke F, Pedersen V. Randomized comparison of conventional and gasless laparoscopic cholecystectomy: operative technique, postoperative course, and recovery. Journal of Gastrointestinal Surgery. 2001;5(3):330-5.

55. Larsen JF, Ejstrud P, Svendsen F, Pedersen V, Redke F. Systemic response in patients undergoing laparoscopic cholecystectomy using gasless or carbon dioxide pneumoperitoneum: a randomized study. Journal of gastrointestinal surgery. 2002;6(4):582-6.

56. Luo HL, Kang CH, Chiang PH. Gasless hand-assisted retroperitoneoscopic nephroureterectomy. Journal of endourology. 2009;23(1):69-74.

57. Nanashima A, Yamaguchi H, Tsuji T, Yamaguchi E, Sawai T, Yasutake T, et al. Physiologic stress responses to laparoscopic cholecystectomy. Surgical endoscopy. 1998;12(12):1381-5.

58. Ninomiya K, Kitano S, Yoshida T, Bandoh T, Baatar D, Matsumoto T. Comparison of pneumoperitoneum and abdominal wall lifting as to hemodynamics and surgical stress response during laparoscopic cholecystectomy. Surgical endoscopy. 1998;12(2):124-8.

59. Ortiz-Oshiro E, Mayol J, Medrano JA, Ruiz LR, Garcia MS, Fdez-Represa JA. Gasless laparoscopic cholecystectomy is not moretime-consuming. Surgical endoscopy. 2001;15(12):1448.

60. Talwar N, Pusuluri R, Arora MP, Pawar M. Randomized controlled trial of conventional carbon dioxide pneumoperitoneum versus gasless technique for laparoscopic cholecystectomy. JK Sci. 2006;8:73-8.

61. Uemura N, Nomura M, Inoue S, Endo J, Kishi S, Saito K, et al. Changes in hemodynamics and autonomic nervous activity in patients undergoing laparoscopic cholecystectomy: differences between the pneumoperitoneum and abdominal wall-lifting method. Endoscopy. 2002;34(08):643-50.

62. Uen Y-H, Chen Y, Kuo C-Y, Wen K-C, Koay L-B. Randomized trial of low-pressure carbon dioxide-elicited pneumoperitoneum versus abdominal wall lifting for laparoscopic cholecystectomy. Journal of the Chinese Medical Association. 2007;70(8):324-30.

63. Vázquez-Rosales MA, Sánchez-Aguilar JM, Hernández-Sierra F, Vázquez-Rosales G, Mandeville PB, Tapia-Pérez JH, et al. Experience with a new design of endoretractor for gasless laparoscopic cholecystectomy. Surgical Laparoscopy Endoscopy \& Percutaneous Techniques. 2010;20(6):416-9.

64. Vezakis A, Davides D, Gibson J, Moore M, Shah H, Larvin M, et al. Randomized comparison between low-pressure laparoscopic cholecystectomy and gasless laparoscopic cholecystectomy. Surgical endoscopy. 1999;13(9):890-3.

65. Wu M-H, Wang M-Y, Yang C-Y, Lee P-H, Lin M-T. Inflammatory response attenuation in patients undergoing gasless laparoscopic gastrectomy. Hepatogastroenterology. 2013;60(123):439-42.

66. Uen Y-H, Liang A-I, Lee H-H. Randomized comparison of conventional carbon dioxide insufflation and abdominal wall lifting for laparoscopic cholecystectomy. Journal of Laparoendoscopic \& Advanced Surgical Techniques. 2002;12(1):7-14.

67. Lindgren L, Koivusalo A, Kellokumpu I. Gasless laparoscopic cholecystectomy: 52. European Journal of Anaesthesiology (EJA). $1997 ; 14(1): 99$.

68. CHEN X-I, ZHANG W-x, YANG X-m. Clinical observation of hysteromyoma cystectomy with gasless laparoscopy. Chinese Journal of Clinical Rational Drug Use. 2012;2012:34.

69. Cavina E, Goletti O, Molea N, Buccianti P, Chiarugi M, Boni G, et al. Trocar site tumor recurrences. Surgical endoscopy. 1998;12(11):1294-6.

70. Jiang J-K, Chen W-S, Wang S-J, Lin J-K. A novel lifting system for minimally accessed surgery: a prospective comparison between "Laparo-V" gasless and CO 2 pneumoperitoneum laparoscopic colorectal surgery. International journal of colorectal disease. 2010;25(8):997-1004.

71. Kitano S, Iso Y, Tomikawa M, Moriyama M, Sugimachi K. A prospective randomized trial comparing pneumoperitoneum and U-shaped retractor elevation for laparoscopic cholecystectomy. Surgical endoscopy. 1993;7(4):311-4. 
72. Lee P-C, Lai P-S, Yang C-Y, Chen C-N, Lai I-R, Lin M-T. A gasless laparoscopic technique of wide excision for gastric gastrointestinal stromal tumor versus open method. World journal of surgical oncology. 2013;11(1):1-7.

73. Ohta J, Kodama I, Yamauchi Y, Takeda J, Noutomi M, Suematsu T, et al. Abdominal wall lifting with spinal anesthesia vs pneumoperitoneum with general anesthesia for laparoscopic herniorrhaphy. International surgery. 1997;82(2):146-9.

74. Surgery JAoAWLfL. Comparison between CO 2 insufflation and abdominal wall lift in laparoscopic cholecystectomy: A prospective multiinstitutional study in Japan. Surgical Endoscopy. 1999;13:705-9.

75. Gurusamy KS, Koti R, Davidson BR. Abdominal lift for laparoscopic cholecystectomy. Cochrane Database of Systematic Reviews. 2013(8).

76. Vezakis A, Davides D, Ammori B, Martin I, Larvin M, McMahon M. Intraoperative cholangiography during laparoscopic cholecystectomy. Surgical endoscopy. 2000;14(12):1118-22.

77. Agnew SP, Small Jr W, Wang E, Smith LJ, Hadad I, Dumanian GA. Prospective measurements of intra-abdominal volume and pulmonary function after repair of massive ventral hernias with the components separation technique. Annals of surgery. 2010;251(5):981-8.

78. Sugerman H, DeMaria E, Felton Wr, Nakatsuka M, Sismanis A. Increased intra-abdominal pressure and cardiac filling pressures in obesity-associated pseudotumor cerebri. Neurology. 1997;49(2):507-11.

79. Barnes GE, Laine GA, Giam PY, Smith EE, Granger HJ. Cardiovascular responses to elevation of intra-abdominal hydrostatic pressure. American Journal of Physiology-Regulatory, Integrative and Comparative Physiology. 1985;248(2):R208-R13.

80. Ishizaki Y, Bandai Y, Shimomura K, Abe H, Ohtomo Y, Idezuki Y. Changes in splanchnic blood flow and cardiovascular effects following peritoneal insufflation of carbon dioxide. Surgical endoscopy. 1993;7(5):420-3.

\section{Tables}

Table 1: MEDLINE search strategy

\begin{tabular}{|c|c|c|}
\hline Search & Search terms & Results \\
\hline 1 & (laparolift or abdolift).ab,ti. & 21 \\
\hline 2 & (gasless or non insufflative or noninsufflative or non pneumoperiton* or nonpneumoperiton*).ab,ti. & 632 \\
\hline 3 & (abdom* adj3 lift*).ab,ti. & 307 \\
\hline \begin{tabular}{|l|}
4 \\
\end{tabular} & $\begin{array}{l}\text { (abdominal wall adj3 (suspen* or elevat*)).mp. [mp=title, abstract, original title, name of substance word, subject } \\
\text { heading word, floating sub-heading word, keyword heading word, organism supplementary concept word, protocol } \\
\text { supplementary concept word, rare disease supplementary concept word, unique identifier, synonyms] }\end{array}$ & \begin{tabular}{|l|}
77 \\
\end{tabular} \\
\hline 5 & (laparos* or laparot* or peritoneoscop* or minimally invasive).ab,ti. & 209927 \\
\hline 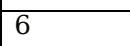 & 1 or 2 or 3 or 4 & 925 \\
\hline 7 & 5 and 6 & 572 \\
\hline
\end{tabular}

Table 2: PICO Tool

\begin{tabular}{|l|l|}
\hline Population & All races with no geographical restrictions. Human adults of at least 18 years old will be included from both genders. \\
\hline Intervention & Gasless laparoscopy \\
\hline Comparators & Conventional laparoscopy or open laparotomy \\
\hline Outcomes & Safety and efficiency of gasless laparoscopy \\
\hline
\end{tabular}


Table 3: Inclusion and Exclusion Criteria

\begin{tabular}{|c|c|}
\hline Inclusion criteria & Exclusion criteria \\
\hline $\begin{array}{l}\text { - Articles published in English and Swedish } \\
\text { - } \\
\text { Articles published on or after } 1992 \\
\text { race or geographic distribution } 18 \text { years old of age from both genders with no restrictions to } \\
\text { - } \\
\text { - }\end{array}$ & $\begin{array}{l}\begin{array}{l}\text { Non-English and non-Swedish } \\
\text { published articles }\end{array} \\
\text { Studies published before } 1992 \\
\text { Patients less than } 18 \text { years of age } \\
\text { Non-gasless laparoscopy procedure } \\
\text { gynaecological surgery } \\
\text { Gasless laparoscopy used for } \\
\text { N<10 in any arm }\end{array}$ \\
\hline
\end{tabular}

Table 4: Data extraction of the outcomes of safety and efficiency of gasless versus conventional laparoscopy from all studies 


\begin{tabular}{|c|c|c|c|c|c|c|c|c|c|c|c|}
\hline \multirow{3}{*}{ Study } & \multicolumn{6}{|c|}{ SAFETY } & \multicolumn{5}{|c|}{ EFFICIENCY } \\
\hline & \multicolumn{2}{|c|}{ Complication } & \multicolumn{2}{|c|}{ Readmission } & \multicolumn{2}{|c|}{ All-cause mortality } & \multicolumn{2}{|c|}{ Length of stay } & \multicolumn{2}{|c|}{ Set up time } & \multirow{2}{*}{$\begin{array}{r}\text { Dura } 1 \\
\text { Gasless }\end{array}$} \\
\hline & Gasless & Con. & Gasless & Con. & Gasless & Con. & Gasless & Con. & Gasless & Con. & \\
\hline $\begin{array}{l}\text { 1. Koivusalo } \\
1998 \\
\end{array}$ & & $\begin{array}{l}\text { - Physio } \\
\text { (increase in } \\
\text { MAP, CVP, } \\
\text { SPO2, PO2, } \\
\text { Core temp, } \\
\text { pulmonary } \\
\text { dynamic } \\
\text { compliance, } \\
\text { minute volume, } \\
\text { urine output } \\
\end{array}$ & & & & & & & & & $\begin{array}{l}108+/ 28 \\
\min \end{array}$ \\
\hline $\begin{array}{l}\text { 2. Koivusalo } \\
1997\end{array}$ & $\begin{array}{l}\text { - Metabolic } \\
\text { urine NAG lower } \\
\text { - Tidal volume } \\
\text { needed to be } \\
\text { increased }\end{array}$ & $\begin{array}{l}\text { urine NAG } \\
\text { higher } \\
(p<0.01) \\
76 \pm 29 \\
\text { minutes }\end{array}$ & & & & & & & & & $\begin{array}{l}76 \pm 29 \\
\text { minutes }\end{array}$ \\
\hline $\begin{array}{l}\text { 3. Koivusalo } \\
1996\end{array}$ & $\begin{array}{l}\text { - Metabolic: } \\
\text { ETCO2 lower }\end{array}$ & - & & & & & & & & & $\begin{array}{l}108+/-28 \\
\min \end{array}$ \\
\hline 4. Uen 2002 & $\begin{array}{l}\text { - Wound } \\
\text { infection (1/48 } \\
\text { patients) }\end{array}$ & $\begin{array}{l}\text { here was a } \\
\text { significant and } \\
\text { sustained } \\
\text { increase in } \\
\text { both levels and } \\
\text { a decrease in } \\
\text { pH after } \\
\text { CO2insufflation } \\
\text { until } \\
\text { desufflation. } \\
\text { higher EtCO2, } \\
\text { PaCO2, and } \\
\text { lower pH and } \\
\text { compliance } \\
\text { - Hemorrhage } \\
\text { ( } 2 / 47 \text { patients) } \\
\end{array}$ & & & & & $\begin{array}{l}89.66+_{-} \\
26.2 \\
(0.072)\end{array}$ & $\begin{array}{l}74.86+ \\
27.5 \\
(0.072)\end{array}$ & $\begin{array}{l}11.56+ \\
3.8 \\
(<0.001)\end{array}$ & \begin{tabular}{|l|}
$4.16+_{-}$ \\
1.4 \\
$(<0.001)$
\end{tabular} & $\begin{array}{l}95.96+_{-} \\
24.1 \\
(<0.012)\end{array}$ \\
\hline $\begin{array}{l}\text { 5. Chang } \\
2011 \\
\end{array}$ & & & & & & & & & & & \\
\hline $\begin{array}{l}6 . \text { Vazquez- } \\
\text { Rosales } 2010\end{array}$ & & & & & & & $24 \mathrm{hrs}$ & $26 \mathrm{hrs}$ & & & $\begin{array}{l}111.44 \\
\text { minutes }\end{array}$ \\
\hline 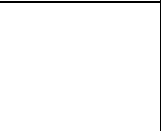 & $\begin{array}{l}\text { Hemorrhage: } \\
35.5+\_11.7 \mathrm{~mL} \\
\text { Average blood } \\
\text { loss }(0.099)\end{array}$ & $\begin{array}{l}\text { Hemorrhage: } \\
40.3+\_12.1 \\
\text { average blood } \\
\text { loss }(0.099)\end{array}$ & & & & & $\begin{array}{l}5.8+ \\
1.2 \\
(0.005)\end{array}$ & $\begin{array}{l}7.2+\_1.2 \\
(0.005)\end{array}$ & & & $\begin{array}{l}129.6+\_36 \\
(p=0.532)\end{array}$ \\
\hline 8. Uen 2007 & $\begin{array}{l}\text { Hemodynamic } \\
\text { instability: } \\
\text { the mean minute } \\
\text { volume revealed } \\
\text { a significant } \\
\text { decrease in } \\
\text { value during } \\
\text { surgery for } \\
\text { members of the } \\
\text { GLC } \\
\text { group }(p<0.05)\end{array}$ & $\begin{array}{l}\text { Hemodynamic } \\
\text { instability: } \\
\text { Pet CO2, } \\
\text { PaCO2, Peak } \\
\text { airway } \\
\text { pressure: } \\
\text { increase } \\
\text { PH: decrease }\end{array}$ & & & & & $\begin{array}{l}3.3+\_1.3 \\
(0.512)\end{array}$ & $\begin{array}{r}3.1 \pm 1.4 \\
(0.512)\end{array}$ & $\begin{array}{l}10.6 \pm 3.5 \\
(0.008)\end{array}$ & $\begin{array}{l}7.5 \pm 5.0 \\
(0.008)\end{array}$ & $\begin{array}{l}98.3 \pm 27.2 \\
(0.008)\end{array}$ \\
\hline 9. Ohta 1997 & $\begin{array}{l}\text { Subcutaneous } \\
\text { emphysema } \\
\text { Inguinal pain } \\
\text { Inguinal seroma } \\
\text { Subcutaneous } \\
\text { bleeding Small } \\
\text { bowel } \\
\text { obstruction } \\
\text { Paralytic ileus } \\
\text { Testis swelling }\end{array}$ & $\begin{array}{l}\text { Hemorrhage + } \\
\text { Subcutaneous } \\
\text { emphysema } \\
\text { Inguinal pain } \\
\text { Inguinal } \\
\text { seroma } \\
\text { Subcutaneous } \\
\text { bleeding Small } \\
\text { bowel } \\
\text { obstruction } \\
\text { Paralytic ileus } \\
\text { Testis swelling }\end{array}$ & & yes & & & & & & & $94.7 \pm 23,4$ \\
\hline $\begin{array}{l}10 . \\
\text { Nanashima } \\
1998 \\
\end{array}$ & & & & & & & $\begin{array}{l}6.7 \pm \\
2.1\end{array}$ & $6.1 \pm 1.5$ & & & $141 \pm 31.5$ \\
\hline $\begin{array}{l}\text { 11. Ortiz- } \\
\text { Oshiro } 2001\end{array}$ & & & 42 patients & 42 patients & & & & & & & \\
\hline $\begin{array}{l}\text { 12. Vezakis } \\
1999\end{array}$ & & $\begin{array}{l}1 \text { patient had } \\
\text { wound }\end{array}$ & 18 patients & 18 patients & & & 8 days & 5 days & & & $95 \mathrm{~min}$ \\
\hline
\end{tabular}

Page 11/19 


\begin{tabular}{|c|c|c|c|c|c|c|c|c|c|c|}
\hline & & infection & & & & & & & & \\
\hline $\begin{array}{l}13 . \\
\text { Ninomiya } \\
1998 \\
\end{array}$ & & $\begin{array}{l}\text { Cardiac: CO, } \\
\text { SV, \%EF } \\
\text { (decreased) } \\
\text { HR increased } \\
\end{array}$ & & & & & & & & $\begin{array}{l}85.0 \pm 11 . t \\
(P>0.05)\end{array}$ \\
\hline $\begin{array}{l}\text { 14. Luo } \\
2009 \\
\end{array}$ & $\begin{array}{l}\text { Hemorrhage: } \\
64.13+_{-} 163.66 \\
(p=0.63)\end{array}$ & $\begin{array}{l}\text { Hemorrhage: } \\
62.8++_{-} 113.5 \\
(p=0.63)\end{array}$ & & & & $\begin{array}{l}7.57+- \\
1.9(6- \\
15) \\
p=0.63\end{array}$ & $\begin{array}{l}8.3+\ldots 1.9 \\
(5-13) \\
p=0.63\end{array}$ & & & $\begin{array}{l}141.83+_{-} \\
32.72(106 \\
200) \mathrm{p}=0.4\end{array}$ \\
\hline $\begin{array}{l}\text { 15. Kitano } \\
1993 \\
\end{array}$ & & $\begin{array}{l}\text { Visceral } \\
\text { perforation: } \\
\text { CBD injury } \\
\end{array}$ & & & & & & & & $52.9 \mathrm{~min}$ \\
\hline $\begin{array}{l}\text { 16. Korkmaz } \\
2002\end{array}$ & $\begin{array}{l}1 / 20 \text { intra- } \\
\text { abdominal } \\
\text { abscess, drained } \\
\text { through } \\
\text { laparotomy }\end{array}$ & & $\begin{array}{l}1 / 20 \text { intra-abdominal } \\
\text { abscess, drained through } \\
\text { laparotomy }\end{array}$ & & $\begin{array}{l}\text { 1 death } \\
\text { from intra- } \\
\text { abdominal } \\
\text { hemorrhage } \\
\text { from } \\
\text { gallbladder } \\
\text { bed in a } \\
\text { cirrhotic } \\
\end{array}$ & 3.7 days & 1.7 days & & & \\
\hline $\begin{array}{l}\text { 17. Cavina } \\
1998 \\
\end{array}$ & & & 10 patients & 20 patients & & & & & & \\
\hline 18. Wu 2013 & $\begin{array}{l}\text { Hemorrhage: } \\
139.1 \text { (24.7) ml } \\
\text { Deep tissue } \\
\text { infection }(1 / 23) \\
1 \text { pneumonia, } 2 \\
\text { fever, } 1 \text { lung } \\
\text { atelectasis, } 1 \\
\text { minor } \\
\text { anastomotic } \\
\text { leak }\end{array}$ & $\begin{array}{l}\text { Hemorrhage: } \\
185.8 \text { (43.0) } \\
\text { ml } \\
\text { Deep tissue } \\
\text { infection } \\
(1 / 12) \\
1 \text { fever } 1 \text { lung } \\
\text { atelectasis } 1 \\
\text { minor } \\
\text { anastomotic } \\
\text { leak }\end{array}$ & & & & $\begin{array}{l}18.7 \\
\pm 1.4\end{array}$ & $20.9 \pm 1.7$ & & & $220.6 \pm 13$ \\
\hline $\begin{array}{l}\text { 19. Larsen } \\
2001\end{array}$ & & $\begin{array}{l}\text { Hemodynamic } \\
\text { instability: } \\
\text { High (Systolic } \\
\text { diameter, } \\
\text { Diastolic } \\
\text { diameter, HR) } \\
\text { Lower } \\
\text { (Fractional } \\
\text { shortening) } \\
\end{array}$ & & & & & & & & $\begin{array}{l}102(40-21 \\
\text { median } \\
\text { (range) }\end{array}$ \\
\hline $\begin{array}{l}\text { 20. Japanese } \\
\text { Association } \\
\text { of Abdominal } \\
\text { Wall Lifting } \\
\text { for } \\
\text { Laparoscopic } \\
\text { Surgery } \\
\text { JAAWLLS) } \\
\text { Anonymous } \\
1999 \\
\end{array}$ & $\begin{array}{l}\text { - minor: } 3 \\
\text { patients with } \\
\text { abnormal LFT, } 1 \\
\text { mild bile leak, } \\
\text { wound infection, } \\
\text { asthma attack, } \\
\text { wound } \\
\text { dehiscence. }\end{array}$ & & $\begin{array}{l}\text { - } 1 \text { patient converted from } \\
\text { peritoneal lift to open } \\
\text { laparotomy due to } \\
\text { bleeding (no further } \\
\text { details provided) }\end{array}$ & & & $\begin{array}{l}8.6+/- \\
4.6\end{array}$ & $\begin{array}{l}8.3+/- \\
3.9\end{array}$ & $\begin{array}{l}13.7 \pm \\
5.0\end{array}$ & $\begin{array}{l}13.2 \pm \\
5.3\end{array}$ & $\begin{array}{l}100.0+/-46 \\
\text { mins }\end{array}$ \\
\hline $\begin{array}{l}\text { 21. Jiang } \\
2010\end{array}$ & $\begin{array}{l}\text { Hemorrhage: } \\
97.1 \pm 64.8 \mathrm{ml}\end{array}$ & $\begin{array}{l}\text { Hemorrhage: } \\
105.0 \pm 95.3 \\
\text { - Delayed } \\
\text { passing of } \\
\text { flatus } \\
\text { - Visceral } \\
\text { perforation }\end{array}$ & & & & $\begin{array}{l}6.3 \pm \\
2.0 \text { days }\end{array}$ & $6.6 \pm 2.5$ & & & $\begin{array}{l}220.0 \pm 55 \\
\text { mins }\end{array}$ \\
\hline $\begin{array}{l}\text { 22. Kim } \\
2002 \\
\end{array}$ & & & & & & & & & & $\begin{array}{l}61 \mathrm{~min}+/- \\
11 \\
\end{array}$ \\
\hline $\begin{array}{l}23 . \\
\text { Koivusalo } \\
2008 \\
\end{array}$ & Pneumonia & & $\begin{array}{l}\text { re-laparoscopy for } \\
\text { internal bleeding from } \\
\text { umbilical port site, } 1 \\
\text { endoscopic retrograde } \\
\text { cholangiopancreatography } \\
\text { on postoperative day } 12 \\
\text { due to bile duct stones } \\
\end{array}$ & & & $\begin{array}{l}6.0 \pm \\
2.1 \\
\text { (mean) }\end{array}$ & $\begin{array}{l}4.7 \pm 1.0 \\
(\text { mean) }\end{array}$ & & & $\begin{array}{l}50.6 \pm 17.2 \\
\text { min (mean) }\end{array}$ \\
\hline 24. Lee 2013 & & & & & & 7.1 & 10.7 & & & 116.6 \\
\hline $\begin{array}{l}\text { 25. Chen } \\
2012\end{array}$ & $\begin{array}{l}\text { Hemorrhage: } \\
43.3 \mathrm{~mL}+_{-} \\
59.4 \mathrm{~mL} \\
(\mathrm{p}<0.05) \text { (mean } \\
+\mathrm{SD})\end{array}$ & $\begin{array}{l}\text { Hemorrhage: } \\
250.0 \mathrm{~mL}_{-} \\
347.9 \mathrm{~mL} \\
(\text { mean }+\mathrm{SD})\end{array}$ & & & & & & & & $\begin{array}{l}141.1 \mathrm{~min}+ \\
52.6 \\
(\mathrm{p}<0.05) \\
(\text { mean }+ \text { si }\end{array}$ \\
\hline $\begin{array}{l}\text { 26. Ortiz- } \\
\text { Oshiro } 2001\end{array}$ & & & & & & & & $\begin{array}{l}25 \text { mins } \\
\text { (median) }\end{array}$ & $\begin{array}{l}35 \text { mins } \\
\text { (median) }\end{array}$ & $\begin{array}{l}60 \text { mins } \\
\text { (median) }\end{array}$ \\
\hline
\end{tabular}

Page 12/19 


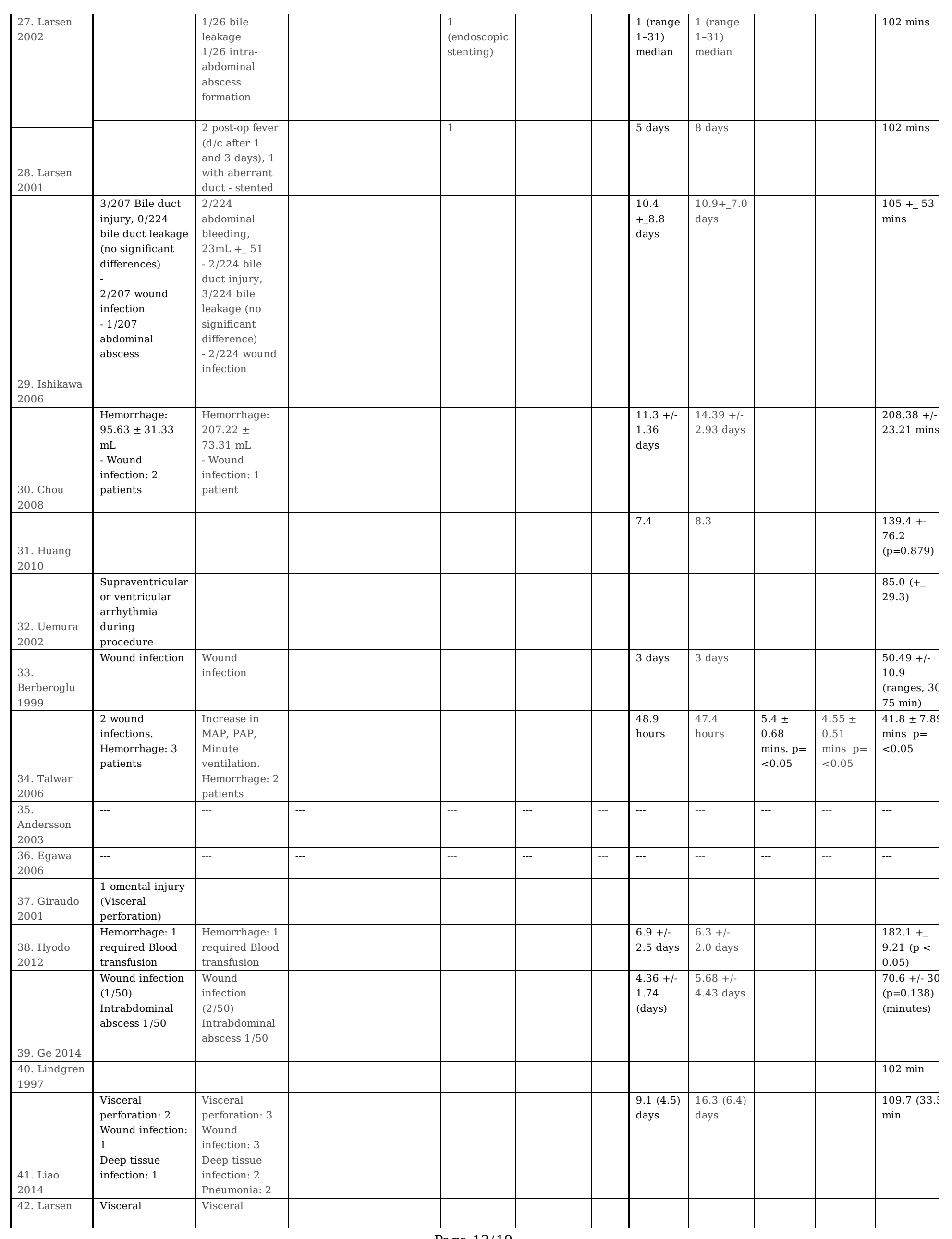

Page 13/19 


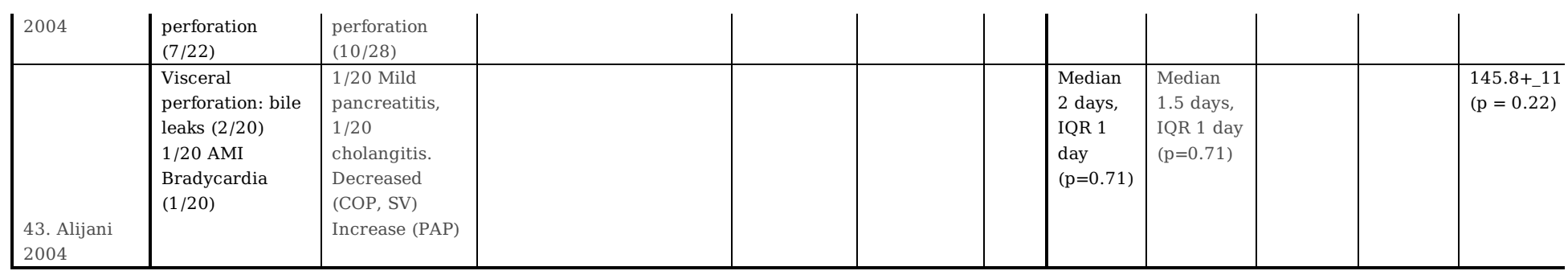

\section{Figures}

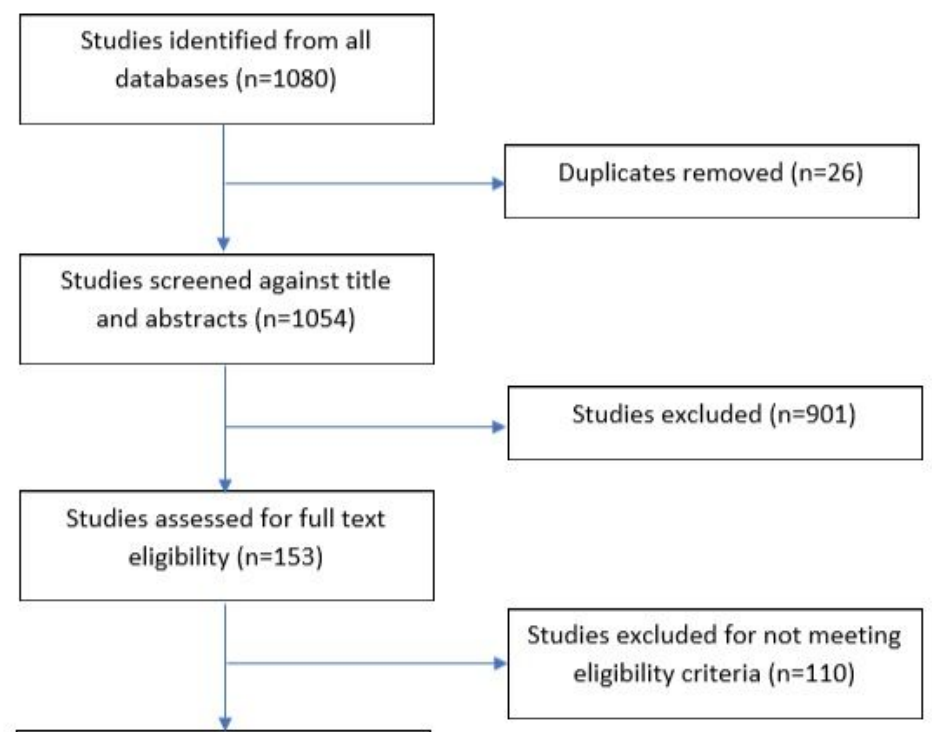

Total studies included for final assessment $(n=43)$

Figure 1

PRISMA Flowchart 


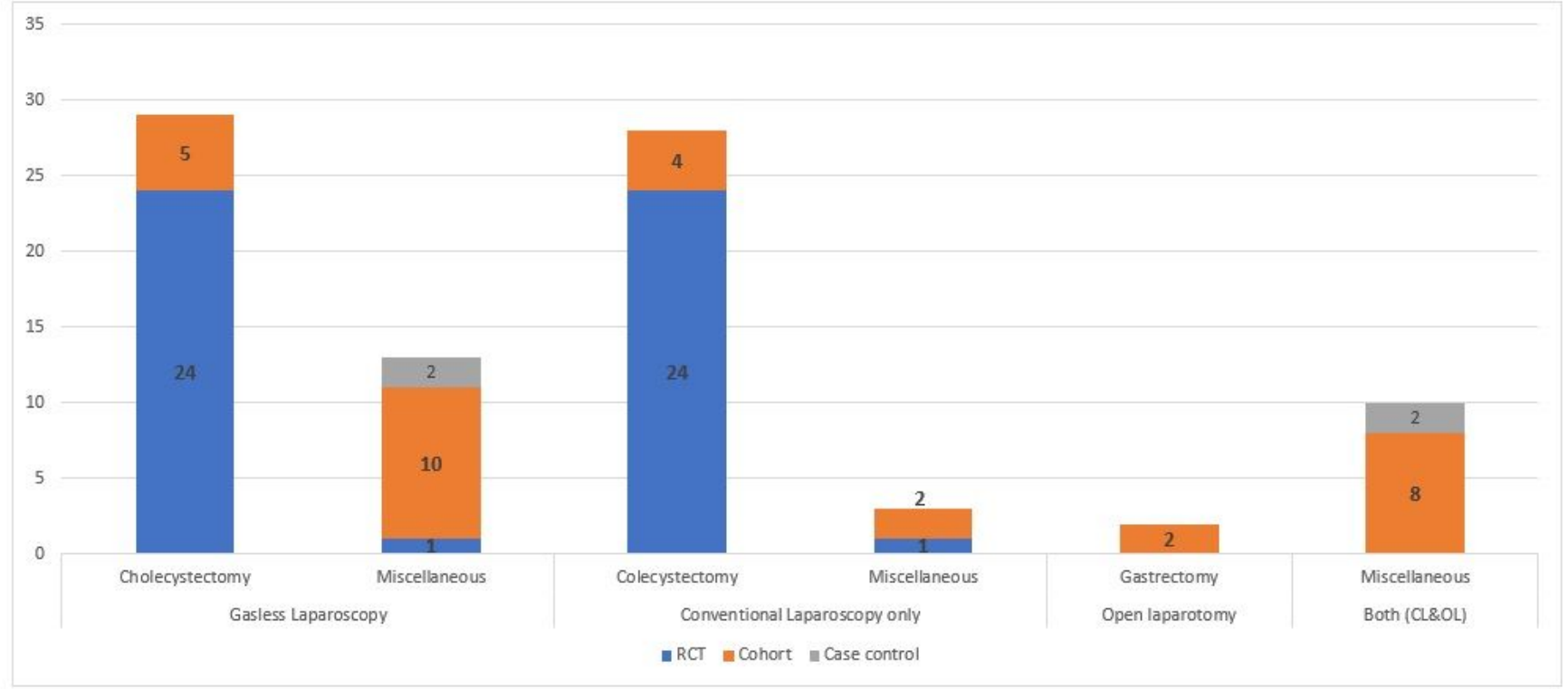

\begin{tabular}{|c|c|c|c|c|c|}
\hline \multicolumn{6}{|c|}{ Total number of patients across all studies reporting the following procedures } \\
\hline \multicolumn{2}{|c|}{ Gasless laparoscopy } & \multicolumn{2}{|c|}{ Conventional laparoscopy } & \multirow{2}{*}{$\begin{array}{r}\text { Open laparotomy } \\
\text { Gastrectomy }\end{array}$} & \multirow{2}{*}{$\begin{array}{c}\text { Both Open and Conventional } \\
\text { Others }\end{array}$} \\
\hline Cholecystectomy & Others & Cholecystectomy & Others & & \\
\hline $\begin{array}{l}793 \\
\text { Cohort: } 118 \\
\text { RCT: } 675\end{array}$ & $\begin{array}{l}366 \\
\text { Cohort: } 281 \\
\text { RCT: } 50 \\
\text { Case control: } 35\end{array}$ & $\begin{array}{l}864 \\
\text { Cohort: } 159 \\
\text { RCT: } 705\end{array}$ & $\begin{array}{l}103 \\
\text { Cohort: } 53 \\
\text { RCT: } 50\end{array}$ & $\begin{array}{l}56 \\
\text { Cohort: } 56\end{array}$ & $\begin{array}{l}269 \\
\text { Case control: } 204 \\
\text { Cohort: } 65\end{array}$ \\
\hline
\end{tabular}

\section{Figure 2}

Distribution of the total number of studies across the main interventions in comparing gasless laparoscopy with either conventional laparoscopy or open laparotomy or both 


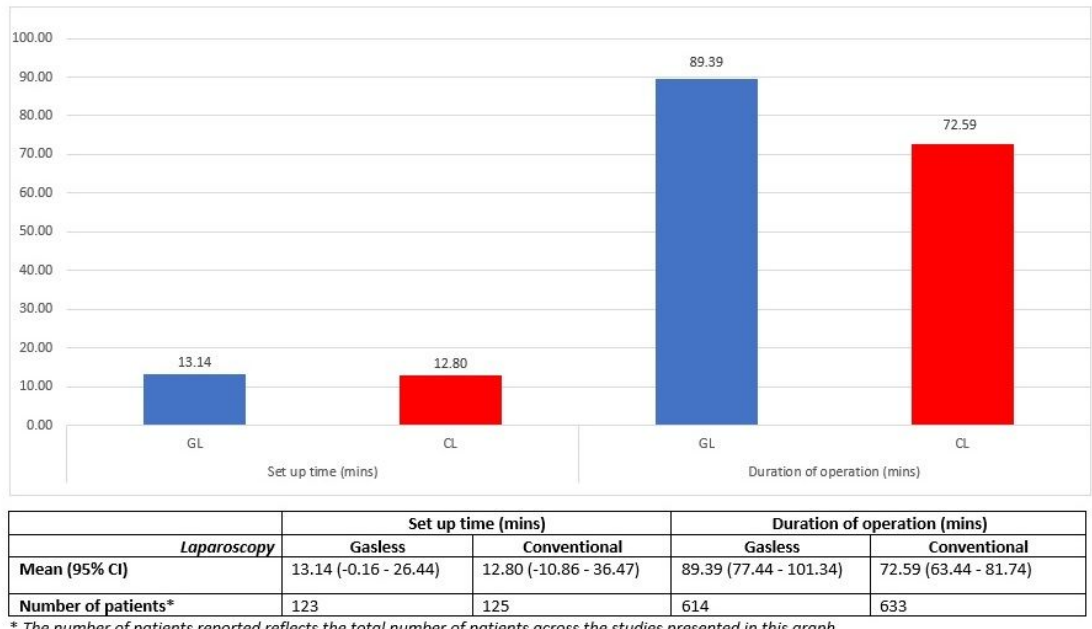

${ }^{*}$ The number of patients reported reflects the total number of patients across the studies presented in this graph

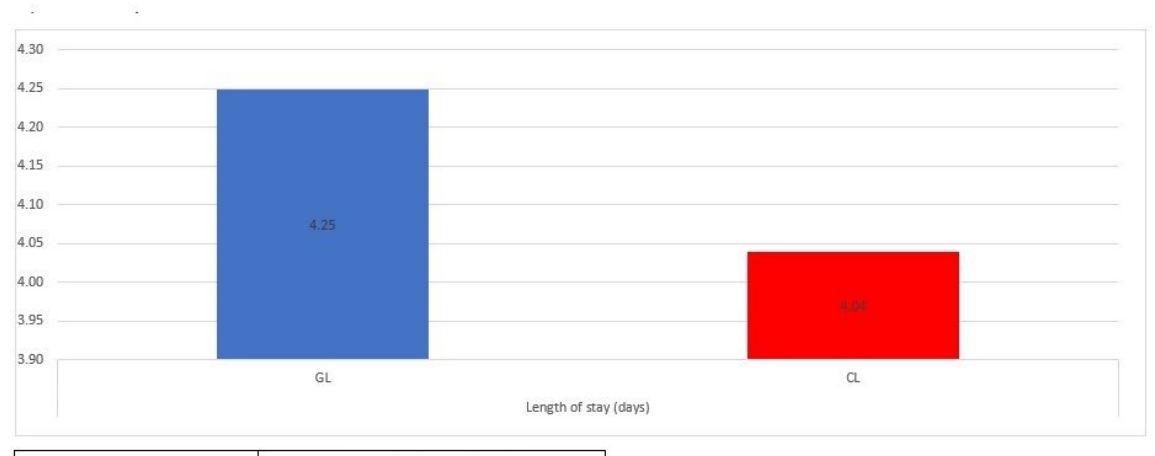

\begin{tabular}{|l|l|l|}
\hline & \multicolumn{2}{c|}{ Length of stay (days) } \\
\hline \multicolumn{1}{|c|}{ Laparoscopy } & \multicolumn{1}{|c|}{ Gasless } & \multicolumn{1}{c|}{ Conventional } \\
\hline Mean (95\% Cl) & $4.25(2.02-6.48)$ & $4.04(1.72-6.36)$ \\
\hline Number of patients & 423 & 440 \\
\hline
\end{tabular}

* The number of patients reported reflects the total number of patients across the studies presented in this graph

\section{Figure 3}

a: Efficiency of Gasless Laparoscopy (GL) versus Conventional Laparoscopy (CL) presented as: mean set up time (mins), mean duration of operation (mins) From 24 RCT studies that reported Cholecystectomies b: Efficiency of gasless laparoscopy (GL) versus conventional laparoscopy (CL) presented as: mean length of stay (days) - From 24 RCT studies that reported Cholecystectomies 

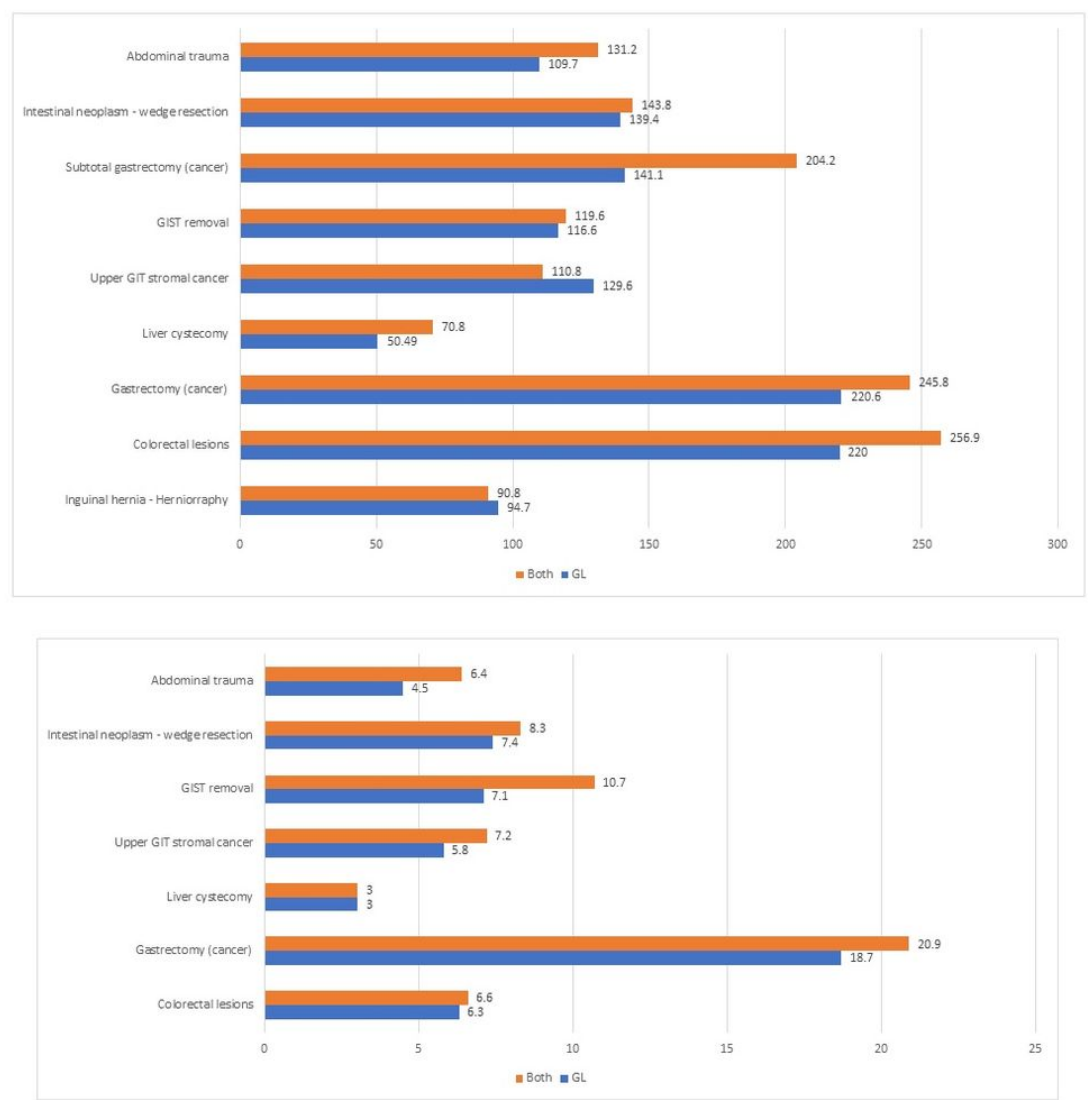

\begin{tabular}{|c|c|c|c|c|}
\hline & \multicolumn{2}{|c|}{ Length of stay (days) } & \multicolumn{2}{|c|}{ Duration of operation (mins) } \\
\hline & Laparoscopy & Both (OL, CL) & Gasless & Both $(\mathrm{OL}, \mathrm{CL})$ \\
\hline Mean $(95 \% \mathrm{Cl})$ & $7.54(2.78-12.31)$ & $9.01(3.72-14.31)$ & $135.8(93.37-178.23)$ & $152.66(101.01-204.3)$ \\
\hline Number of patients* & 167 & 155 & 235 & 217 \\
\hline
\end{tabular}

\section{Figure 4}

a: Efficiency of gasless laparoscopy (GL) versus both conventional laparoscopy and open laparotomy from non-RCT studies (10 studies) presenting the duration of operation in minutes b: Efficiency of GL versus both CL and OL from non-RCT studies (10 studies) presenting the length of stay in days 


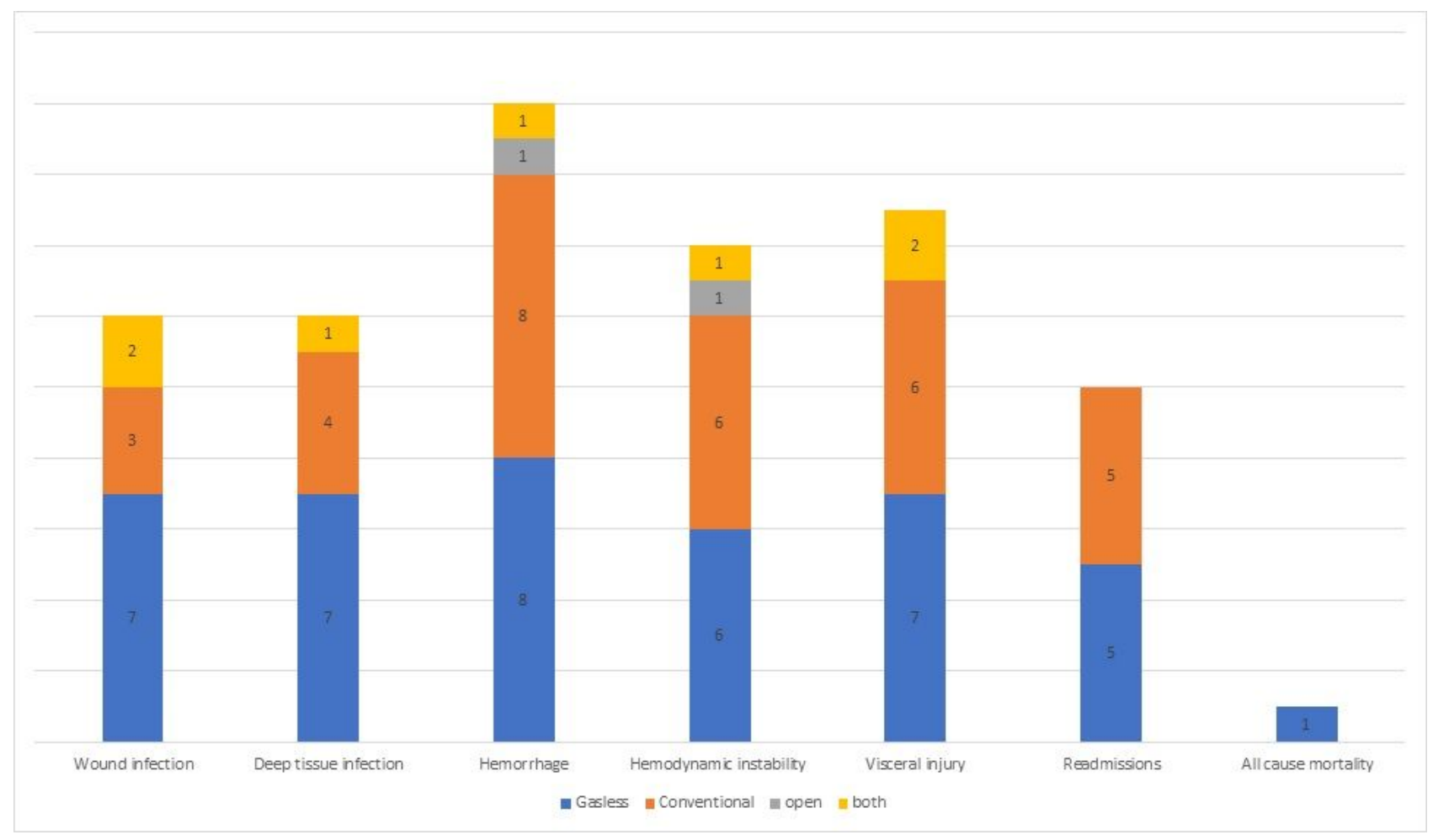

\section{Figure 5}

Bar graph showing the number of reported studies on the safety for gasless versus conventional laparoscopy, open laparotomy or studies reporting both; includes the 1) complications (wound infection, deep tissue infection, haemorrhage. Hemodynamic instability, visceral injury), 2) readmissions, and 3) allcause mortality

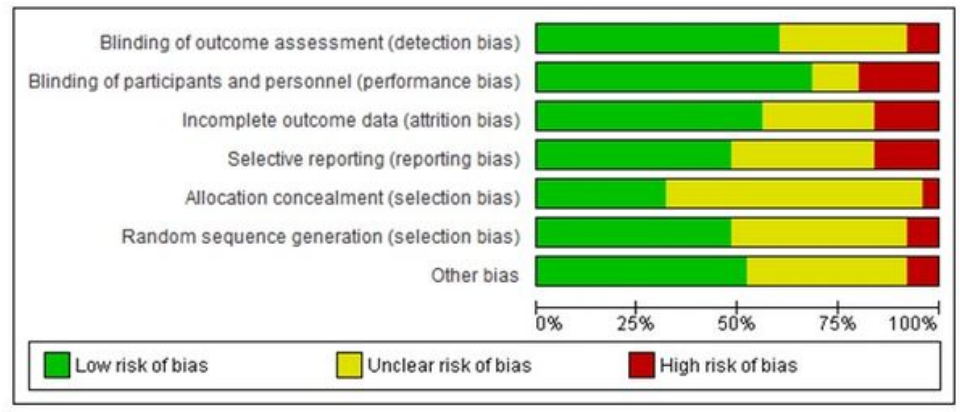

\section{Risk of Bias in RCTs}

Bias 1: Outcomes - detection bias Bias 2: Participants - Performance bias Bias 3: Incomplete Outcome (Attrition Bias) Bias 4: Selective outcomes (Reporting Bias) Bias 5: Allocation Concealment

Bias 6: Random sequence generation

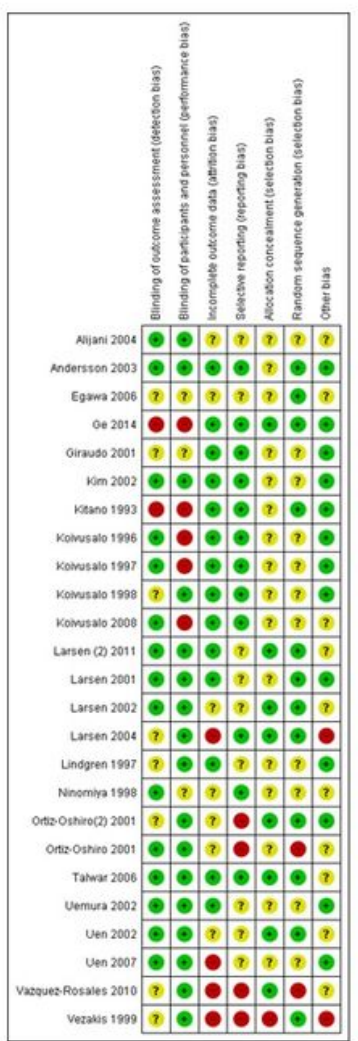




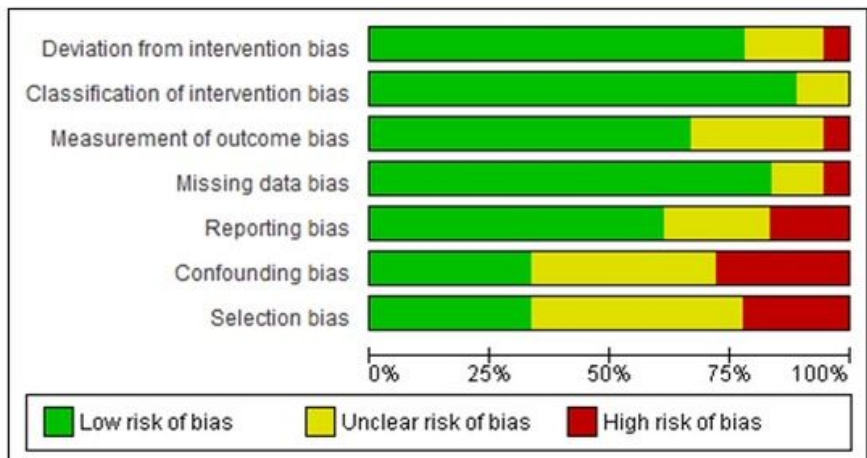

Non-RCTs:

Bias 1: Intervention bias Bias 2: Measurement outcome bias

Bias 3: Missing data bias

Bias 5: Risk of confounding bias

Bias 6: Selection bias
Bias 4: Reporting bias

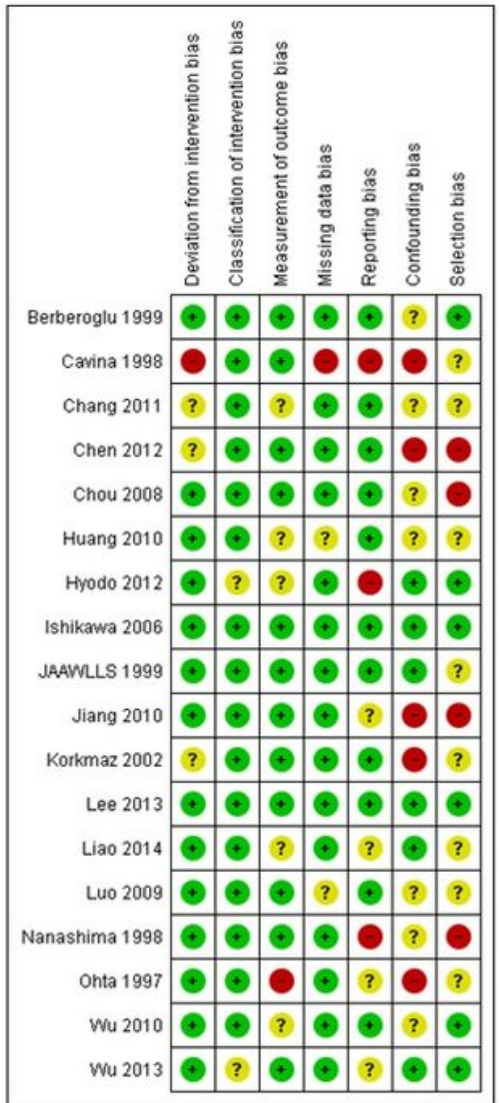

\section{Figure 7}

a: Cochrane risk of bias graph - assessment of non-randomized studies b: Cochrane risk of bias summary of all non-randomized studies 